\title{
The Effects of Orientation, Ventilation, and Varied WWR on the Thermal Performance of Residential Rooms in the Tropics
}

\author{
Nedhal Ahmed M. Al-Tamimi (Corresponding author) \\ School of Housing, Building and Planning, Universiti Sains Malaysia \\ 11800, Minden, Penang, Malaysia \\ Tel: 60-12-4499-760 E-mail: nedhalali.rd08@student.usm.my \\ Sharifah Fairuz Syed Fadzil \\ School of Housing, Building \& Planning, Universiti Sains Malaysia \\ Tel: 60-17-3311-998 E-mail: sfsf@usm.my \\ Wan Mariah Wan Harun \\ School of Housing, Building \& Planning, Universiti Sains Malaysia \\ Tel: 60-19-4644-393 E-mail: mariah@usm.my
}

Received: November 24, 2010

Accepted: December 21, 2010

doi:10.5539/jsd.v4n2p142

The research is funded by Universiti Sains Malaysia (USM)

\begin{abstract}
Building orientation is a significant design consideration, mainly with regard to solar radiation and wind. In predominantly hot humid regions like Malaysia which receives sunlight all year around, buildings should be oriented to minimize solar gain and maximize natural ventilation. This paper describes an investigation into the effect of building orientation in view of solar radiation absorptance of exterior wall, varied area ratio of glazed window to wall and the effect of natural ventilation on the thermal performance for residential building in tropical region. The Fajar Harapan building which is a postgraduate student residential building is oriented in the east west directions, and located in USM Campus, Penang. Two rooms were selected for the case study, one facing the east and the other facing the west direction. The differences between in/out door air temperature and air velocity of both rooms were measured from the field directly using the comprehensive data logger BABUC/M. This data have been analyzed and investigated. The results show that east windows have more obvious effect on increasing indoor air temperature than west windows, that is applicable for ventilated or unventilated rooms.
\end{abstract}

Keywords: Thermal comfort, Building orientation, WWR, Tropical region

\section{Introduction}

Architecturally, the hot and humid region is one of the hardest climates to ameliorate through design. This is due to the high humidity and daytime temperatures that result in high indoor temperatures exceeding the ASHRAE summertime comfort upper limit of $26^{\circ} \mathrm{C}$ for most of the year (Sabarinah Sh. Ahmed, 2008). Glazed building facade imposes itself as an icon for the developing cities. This large area of glazing in each facade needs protection against overheating and sun glare in tropical region, especially when it faces east or west direction.

In Malaysia for example, east and west façade expostulate to direct sun radiation every morning and evening, while north façade faces sun radiation during May, June July and August, and south façade faces it during November, December, January and February. Therefore building orientation, particularly in tropical region should be seriously considered according to its interaction with solar radiation as well as wind direction. Givoni (1994) reported that in hot humid regions the provision of effective cross ventilation under the local wind direction is the major factor that may affect the building orientation. Air movements inside a building depend not only on external wind velocity, but also largely on the architectural parameters. Architectural means for achieving this aim include conventional design element such as position and orientation of building, roof shape, balcony configuration, type and location of windows, partition and furniture arrangement.

\section{Climate Responsive Design Strategies in Hot and Humid Region}

Climate responsive design of buildings is important not only because of the comfort and energy saving implications for its users, but also because it helps preserve valuable resources in our planet (La Roche, P., Liggett, R, 2001). Unfortunately, new building envelope designs are developed to meet the client's requirements without much concern to the local climate and with no objective to conserve energy. This has undoubtedly 
disregarded the climate as a design determinant in building envelope design process. As a result, these have contributed to an overall poor thermal performance of the buildings which became more dependent on artificial means to provide comfortable thermal environment at high energy consumption.

The monitored building is located at University Science Malaysia campus, Penang. Local latitude is $5.35 \circ \mathrm{N}$ and longitude is $100.30^{\circ} \mathrm{E}$. The location has a Malaysian tropical climate, uniformly high temperatures, high humidity and abundant rainfall throughout the year. It has a diurnal temperature range of minimum $23-27{ }^{\circ} \mathrm{C}$ and maximum $30-34{ }^{\circ} \mathrm{C}$, with a mean annual $\mathrm{RH}$ value of $84 \%$. According to 10 -Day Agromet Bulletin, issued by Malaysian Meteorological Department (MMD, 2009) for the month of March 2009 showed that, typical solar radiation of Penang Island is more than $6.1 \mathrm{kWh} / \mathrm{m}^{2}$ per day. Presently, this energy cannot be explored efficiently, it creates discomfort and becomes a problem that needs to be extracted from the building space.

\subsection{Impact of Envelope Design on Thermal Performance}

Building envelope is one of the most important components with respect to total heat gain of whole building and overall heat transfer coefficient which determines heat gain through the building envelope. An analysis of the building energy consumption in Hong Kong, Singapore and Saudi Arabia for example gives a result that, the building envelope design accounts for $36 \%, 25 \%$ and $43 \%$ of the peak cooling load respectively (Lam and $\mathrm{Li}$, 1999; Grace Cheok, 2008; Al-Najem. 2002).

Despite of the availability of many experimental and numerical research studies conducted in some tropical warm and humid climates such as China, Taiwan, Singapore, Saudi Arabia, India, Indonesia, Thailand and Malaysia to investigate the impact of building envelope in internal thermal performance or its impact energy consumption, there is only a limited amount of research literature on building envelope fenestrations through the climate responsive design requirements to achieve energy-efficient building in hot and humid climate. In this paper, the relevant literature in the above aspects will be reviewed.

\subsection{Influence of Varied Orientation}

Selecting the most optimal building orientation is one of the critical energy efficient design decisions that could have impact on building envelope energy performance, as it can be used to minimize the direct sun radiation into the buildings through windows, building openings as well as external opaque walls. It will be most affected for full glazed building. Syed Fadzil S. F. et al, (2004) studied the effect of direct sunlight penetration and daylight distribution in a building with 12 bays of continuous orientation located in a Tropical climate in Penang. The results indicated that the best bay with the least sunlight penetration is with orientation $0 \circ$ and the worst is with $240^{\circ}$; those with orientations $30^{\circ}, 180^{\circ}, 330^{\circ}, 60^{\circ}, 90^{\circ}, 300^{\circ}, 150^{\circ}, 120^{\circ}, 210^{\circ}$ and $270^{\circ}$ follows in order. In this context, the bay with the least direct sunlight penetration is considered the best as it receives the least heat gain thus reducing the cooling load and saving energy. It is also the best bay with regard to minimum glare problems. Dirk Rilling reported a study in (2007) which investigated the impact of changes in orientation and insulation appliances, they showed up to $43 \%$ lower cooling load. Results have also indicated a positive impact in the consumption of electrical power. However, the case studies were applied on two different designs of residential buildings located in Malacca, Malaysia (Dirk Rilling et al, 2007).

Joseph reported a study in (2003) which investigated the impact of the façade's surfaces orientation on the intensity of the direct and indirect solar radiation. The results showed that the north has the lowest solar intensity which varies from $43.6 \mathrm{~W} / \mathrm{m}^{2}$ in October to $65.5 \mathrm{~W} / \mathrm{m}^{2}$ in July. Solar intensity on the east and west surfaces is similar, the 6-month mean solar intensity is 86.1 and $89.6 \mathrm{~W} / \mathrm{m}^{2}$ for the east and west surfaces, respectively. The 6-month mean intensity on the south surface is $74.5 \mathrm{~W} / \mathrm{m}^{2}$ somewhere between the north and the east/west (Joseph C. Lam et al, 2003).

\subsection{Influence of Natural Ventilation $N V$}

Natural ventilation is the intentional flow of outdoor air through an enclosure under the influence of wind and thermal pressures through controllable openings. It can effectively control temperature particularly in hot and humid climate. Temperature control by natural ventilation is often the only means of providing cooling when mechanical air-conditioning is not available (Tony Rofail, 2006). Natural ventilation in this work defined as the increase in building thermal performance due to an increase in natural air movement as a passive cooling strategy. In a tropical climate the improvements in comfort by NV range between $9 \%$ and $41 \%$ (Kuala Lumpur in April). In a temperate climate the improvements vary between $8 \%$ and $56 \%$. The results showed that NV has a good potential in tropical and temperate climates (M. Haase et al, 2008).

\subsection{Influence of Glazed Fenestration Systems}

Windows, doors, and skylights have a significant impact on the thermal performance of the building envelope. Windows can also have a strong influence on the use, productivity, and comfort of the people who occupy the building. Study reported by Jinghua Yu (2006) showed that heat gain through the exterior window accounts for $25-28 \%$ of the total heat gain, adding to the infiltration. It is up to $40 \%$ (Yang and Yu, 2002) in hot summer and cold winter zone. Glazed windows are becoming an important component of contemporary architecture. They allow natural light, offer a visual communication with outdoors, reduce a structural load and enhance aesthetic 
appearance of buildings (Datta, 2001; Al-Saadi, 2006). A proper selection for the optimal area of the glass and applying natural ventilation system can reduce the negative effect of solar radiation in increasing the indoor air temperature (Al-Tamimi, N. and Syed Fazil, 2010). Therefore, with many benefits that the glazed windows do offer to the occupants and the designers, they are not free of introducing problems if they are not properly selected. Many parameters in fenestration system are important when thermal performance is evaluated. However, the two parameters evaluated for thermal performance for this study are as follows:

Impact of Window to Wall Ratio (WWR)

Impact of natural ventilation

\section{Methodology and Description of the Case Study}

The method used in this study is experimental, technical and quantitative in nature. It focuses to study the influences of orientation, natural ventilation and varied WWR to the indoor environmental performance. Environmental field data was collected at 10 minutes intervals monitoring the temperature, measuring the air velocities; using data logger, i.e. BABUC/M. A series of continuous environmental data measurements were undertaken in Fajar building during the highest month of average temperature and solar radiation in Penang, i.e. ( $6^{\text {th }}$ to $31^{\text {st }}$ March 2009).

The case study selected was a building called Fajar Harapan located at the University Science Malaysia Penang. The building consists of four storey, the topmost floor chosen as the shading is similar and no effects of outdoor shading like trees were found, and functions as a student dormitory complex. Two rooms at Fajar Harapan dormitories were used for this study, the first facing East (E1) orientation and the second West (W1) orientation (refer to Figure 1., 2. and 3.) as the typical worst case orientation scenario in the tropics in terms of direct solar radiation in the morning and afternoon hours. The overall floor area for each room is $12.9 \mathrm{~m}^{2}$, the building is oriented in such a way that openings have mainly exposure to east and west direction, the window-to-wall ratio (WWR: net glazing area to gross exterior wall area) of both rooms is $50 \%$ and all windows include steel grades.

For analyzing the effect of glazed area, the performance of E1 and W1 in terms of air temperatures was monitored in relation to outdoor air temperatures $\mathrm{T}_{0}$. The existing WWR of $50 \%$ were compared with $0 \%$ (i.e. covering up the whole glazed area with polystyrene foam boards) with no influence of natural ventilation (i.e. windows and doors closed).

For studying the effect of natural ventilation the same E1 and W1 rooms were used and this time all windows and doors were opened. WWR of $50 \%$ were compared to WWR of $25 \%$. Data on selected days were taken for graphs and analysis. Table 1. described the material component of the building envelope.

\section{Results and Findings}

\subsection{Effect of windows orientation on thermal performance with consideration to WWR and NV}

In considering the orientation of a building, the main issue is the orientation of the windows. The potential of the solar penetration through windows in hot climate, and its effect on the elevation of the indoor temperature, depends greatly on the orientation of the windows (Givoni, 1994). The net effect of the window system in building envelope design depends on the window orientation, window wall ratio WWR and weather conditions.

\subsubsection{Unventilated Rooms With WWR $=50 \%$}

In this analysis, different designs of window system are taken into consideration in order to observe the interaction of the heat gains and/or loss on thermal comfort. The result (Figure 4.) showed that east windows have more obvious effect on increasing indoor air temperature than west windows for the whole time of the day. That is applicable for ventilated or unventilated rooms. With no ventilation, the maximum, average and minimum differences in in/outdoor temperature for western rooms were $+5.6^{\circ} \mathrm{C},+2.4^{\circ} \mathrm{C}$ and $-1.7^{\circ} \mathrm{C}$ respectively, while it was $+3.9^{\circ} \mathrm{C}+0.63^{\circ} \mathrm{C}$ and $-2.9^{\circ} \mathrm{C}$ respectively, that means the average air temperature in east room is more by $1.78^{\circ} \mathrm{C}$ than the recorded in west room. The peak temperature in east room was $35.17^{\circ} \mathrm{C}$ occurred at 9:20am, while it was $32.20^{\circ} \mathrm{C}$ in the west room at 5:30pm.

\subsubsection{Ventilated Rooms With WWR $=50 \%$}

In hot and humid regions where the diurnal temperature range is small, constant daytime ventilation across the skin, either naturally or mechanically, may not provide thermal comfort without additional assistance. In many cases, daytime ventilation alone cannot keep indoor temperatures below those of the outdoors (Givoni, 1981). The results (Figure 5.) showed that with applying natural ventilation NV, the temperature in both rooms slightly decreased, but the eastern room remain hotter than eastern. the maximum, average and minimum differences in in/outdoor temperature for eastern room were $+3.5^{\circ} \mathrm{C},+0.66^{\circ} \mathrm{C}$ and $-2^{\circ} \mathrm{C}$, while it was $+2.9^{\circ} \mathrm{C},+0.45^{\circ} \mathrm{C}$ and $-2.6^{\circ} \mathrm{C}$ for the western room, that means the average time of keeping east and west room below $28.6^{\circ} \mathrm{C}$ are $41.7 \%$ and $57 \%$ respectively.

\subsubsection{Ventilated rooms with $\mathrm{WWR}=25 \%$}

Significant decrease in indoor air temperature in both rooms occurred when glazed area ratio of windows were changed from $50 \%$ to $25 \%$ with applying cross ventilation strategy. That is because of the reduction in the total 
solar radiation coming through window. The result (Figure 6.) shows that, the peak temperature in east and west room became closer to each other i.e. $29.82^{\circ} \mathrm{C}$ and $29.27^{\circ} \mathrm{C}$ respectively. The maximum, average and minimum differences in in/outdoor temperature for eastern rooms were $+2.6^{\circ} \mathrm{C},+1^{\circ} \mathrm{C}$ and $-2^{\circ} \mathrm{C}$, while it was $+2^{\circ} \mathrm{C}+0.5^{\circ} \mathrm{C}$ and $-3.1^{\circ} \mathrm{C}$ for western room, that means $80 \%$ of the time, indoor air temperature for both rooms will be below $28.6^{\circ} \mathrm{C}$.

\subsubsection{Opaque wall / Unventilated Room with WWR $=0 \%$}

In this case, the windows are fully covered. At day and night time the average temperatures inside both rooms are similar, within or less than $0.5^{\circ} \mathrm{C}$ difference. On the other hand, the difference in day and night temperature for both rooms was about $2^{\circ} \mathrm{C}$, however, it reached $7^{\circ} \mathrm{C}$ in existing case (WWR $=50 \%$, unventilated). This is due to the avoidances in solar gain through the glazed windows. The result in (Figure 7.) shows that, the maximum, average and minimum differences in in/outdoor temperature for eastern rooms were $+6^{\circ} \mathrm{C},+1.3^{\circ} \mathrm{C}$ and $-4^{\circ} \mathrm{C}$, while it was $+5.7^{\circ} \mathrm{C},+0.67^{\circ} \mathrm{C}$ and $-5^{\circ} \mathrm{C}$. This big difference in in/out side temperature occurred because of the thermal insulated envelope, and indicates that the building is able to protect from the intense heat from outside.

\subsection{Effect of Natural ventilation on thermal performance:}

Sabarinah Sh. A., et al, (2007) reported that, the comfort band for Malaysia for all building types is between 23.6 and $28.6^{\circ} \mathrm{C}$. However, Zainazlan M. Z. et al, (2007) suggested that, the occurrence of thermal comfort in Malaysian buildings can be achieved below $28.69^{\circ} \mathrm{C}$. Figure 5., and 6., showed that without air flow, there is no count of temperature below the neutral temperature while about $80 \%$ of the day time occurrence below $28.6^{\circ} \mathrm{C}$ with considering WWR $=25 \%$. An air flow of $0.7 \mathrm{~m} / \mathrm{s}$ will give reduction in temperature from $29.5^{\circ} \mathrm{C}$ to $27.6^{\circ} \mathrm{C}$, and increase in indoor thermal comfort, While an air flow if less than $0.2 \mathrm{~m} / \mathrm{s}$ would not be as effective.

\section{Conclusion}

Appropriate selection for windows orientation, optimal size of the glass and applying natural ventilation system, can reduce the negative effect of solar radiation in increasing indoor air temperature. The main findings of this paper are summarized as follows:

According to climate condition and field measurements, the existing scenario for the case study shows in table 2 . that, east orientation is more sensitive to solar radiation. The east rooms are always hotter than those in west direction. And even by applying natural ventilation, changing WWR or not, the average differences in in/out door air temperature in east rooms is higher, comparing with west rooms. Thus, the percentage time of being the room temperature below the recommended level in tropical region -i.e. $28.6^{\circ} \mathrm{C}$ - in east room is less than the west, under all conditions. Unless with WWR $=25 \%$ they are almost same.

More care should be taken in the primary stage of design to avoid any opening in east or west direction, unless there is need for that. In this case, intensive consideration should be taken for the following variables:

Using thermal insulation for the exterior walls with less $U$ value.

Select a proper shading devices.

Select a type of glass that have small $U$ value, to minimize solar penetration.

Based on the above results, it can be concluded that, in general, thermal comfort can be improved by applying natural ventilation and $\mathrm{WWR}=25 \%$. Thus, the needs for applying mechanical ventilation is necessary to improve occupiers thermal comfort.

\section{References}

AL-Najem A. A. (2002). The Architectural Category and its importance to measure the electrical energy demand and to identify effective conservation measures. The first Symposium on Energy Conservation and Management in Buildings Conference, SAK, (I), 99-110.

Al-Tamimi, N. A. and S. F. Syed Fadzil. (2010). Experimental and Simulation Study for Thermal Performance Analysis in Residential Buildings in Hot-Humid Climate (Comparative Study). Journal of Science \& Technology, $15(1), 17-25$.

Al-Saadi, S. N. (2006). Envelope design for thermal comfort and reduced energy consumption in residential buildings. Architectural Engineering Dept. SAK, King Fahd University of Petroleum and Minerals. Master thesis, Master thesis.

Cheok Grace. (2008). Proposed Legislative Framework on Environmental Sustainability for Buildings.

Datta, G. (2001). Effect of fixed horizontal louver shading devices on thermal perfomance of building by TRNSYS simulation. Renewable Energy 23 (3-4), 497-507.

Dirk Rilling et al. (2007). Thermal simulation as design tool for residential buildings in Southeast Asia. Jurnal Alam Bina, 9 (3), 45-54

Givoni B. (1981). Conservation and the use of integrated-passive energy systems in architecture. Energy \& Buildings. 3 (3), 213-227. 
Givoni, B. (1994). Passive and Low Energy Cooling of Buildings. New York, International Thomson Publishing ITP.

Haase M. and Amato A. (2009). An investigation of the potential for natural ventilation and building orientation to achieve thermal comfort in warm and humid climates. Solar Energy, 83, 389-399.

Hyde R. and Sabarinah Sh. A. (2008). Bioclimatic housing, innovative designs for warm climates. Earthscan UK \& USA.

Jinghua Yu el at. (2008). Low-energy envelope design of residential building in hot summer and cold winter zone in China. Energy and Buildings, 40, 1536-1546.

La Roche, P., Liggett, R. (2001). A Web Based Assistant for the Design of Climate Responsive Buildings. Architectural Science Review, 44, 437-448.

Lam J.C., Li D. H. W. (1999). An analysis of daylighting and solar heat for cooling-dominated office buildings. Solar Energy. 65 (4), 251-262.

Rofail Tony. (2006). Natural Ventilation in Buildings. NEERG Seminar.

Syed Fadzil, S.F. and Sia Sheau J. (2004). Sunlight control and daylight distribution analysis: the KOMTAR case study. Building and Environment, 39 (6), 713-717.

Zainazlan Md Zain. (2007). Hot and humid climate: prospect for thermal comfort in residential building. Desalination, 209, 261-268.

Table 1. Physical specifications of the building (from inside to outside)

\begin{tabular}{rlrrrl}
\hline \multicolumn{2}{c}{ External walls } & \multicolumn{2}{c}{ Internal walls } & \multicolumn{2}{c}{ Roof (from inside to outside) } \\
\hline Thickness & Material & Thickness & Material & Thickness & Material \\
\hline $20 \mathrm{~mm}$ & Plaster & $20 \mathrm{~mm}$ & Plaster & $10 \mathrm{~mm}$ & hanging ceiling \\
\hline $110 \mathrm{~mm}$ & Clay brick & $110 \mathrm{~mm}$ & Clay brick & $0-2400 \mathrm{~mm}$ & Air Gap (Attic) \\
\hline $20 \mathrm{~mm}$ & Plaster & $20 \mathrm{~mm}$ & Plaster & $0.6 \mathrm{~mm}$ & Aluminum Foil \\
\hline & & & $50 \mathrm{~mm}$ & Clay Tiles \\
\hline
\end{tabular}

Table 2. Conclusion for all conditions applied to the existing building

\begin{tabular}{|c|c|c|c|c|c|c|c|c|c|}
\hline Date & $\begin{array}{c}\text { Room } \\
\text { orientatio } \\
n\end{array}$ & WWR & $\begin{array}{c}\text { Vent. } \\
\text { condition }\end{array}$ & $\begin{array}{c}\text { Max } \\
\text { in/temp }\end{array}$ & $\begin{array}{c}\text { Ave } \\
\text { in/temp }\end{array}$ & $\begin{array}{c}\text { Min } \\
\text { in/temp }\end{array}$ & $\begin{array}{c}\text { Ave diff. } \\
\text { Temp } \\
\text { In/out }\end{array}$ & $\begin{array}{l}\text { Time of } \\
\text { the peak }\end{array}$ & $\begin{array}{l}\% \text { Time } \\
\text { Temp }< \\
28.6^{\circ} \mathrm{C}\end{array}$ \\
\hline \multirow{2}{*}{$\begin{array}{l}7 \text { and } \\
8 / 3 / 09\end{array}$} & East & \multirow{2}{*}{$50 \%$} & \multirow{2}{*}{$\begin{array}{c}\text { Unventilate } \\
\mathrm{d}\end{array}$} & 35.17 & 30.56 & 28.22 & +2.41 & $9: 20 \mathrm{am}$ & $8.3 \%$ \\
\hline & West & & & 32.20 & 28.76 & 27.03 & +0.63 & $5: 30 \mathrm{pm}$ & $53.5 \%$ \\
\hline \multirow{2}{*}{$\begin{array}{c}10 \text { and } \\
13 / 3 / 09\end{array}$} & East & \multirow{2}{*}{$50 \%$} & \multirow{2}{*}{$\begin{array}{c}\text { Natural } \\
\text { ventilated }\end{array}$} & 31.24 & 28.40 & 25.36 & +0.66 & 9:20am & $41.7 \%$ \\
\hline & West & & & 32.92 & 28.18 & 25.40 & +0.45 & $6: 10 \mathrm{pm}$ & $57.0 \%$ \\
\hline \multirow{2}{*}{$\begin{array}{c}16 \text { and } \\
21 / 3 / 09\end{array}$} & East & \multirow{2}{*}{$25 \%$} & \multirow{2}{*}{$\begin{array}{c}\text { Natural } \\
\text { ventilated }\end{array}$} & 29.82 & 27.50 & 25.28 & +1.01 & $1: 00 \mathrm{pm}$ & $79.3 \%$ \\
\hline & West & & & 29.27 & 26.98 & 25.21 & +0.50 & $3: 10 \mathrm{pm}$ & $82.5 \%$ \\
\hline \multirow{2}{*}{$\begin{array}{c}28 \text { and } \\
29 / 3 / 09\end{array}$} & East & \multirow{2}{*}{$0 \%$} & \multirow{2}{*}{$\begin{array}{c}\text { Unventilate } \\
\mathrm{d}\end{array}$} & 30.15 & 29.00 & 27.91 & +1.27 & $6: 50 \mathrm{pm}$ & $40.3 \%$ \\
\hline & West & & & 30.22 & 28.50 & 27.53 & +0.76 & $6: 10 \mathrm{pm}$ & $58.3 \%$ \\
\hline
\end{tabular}




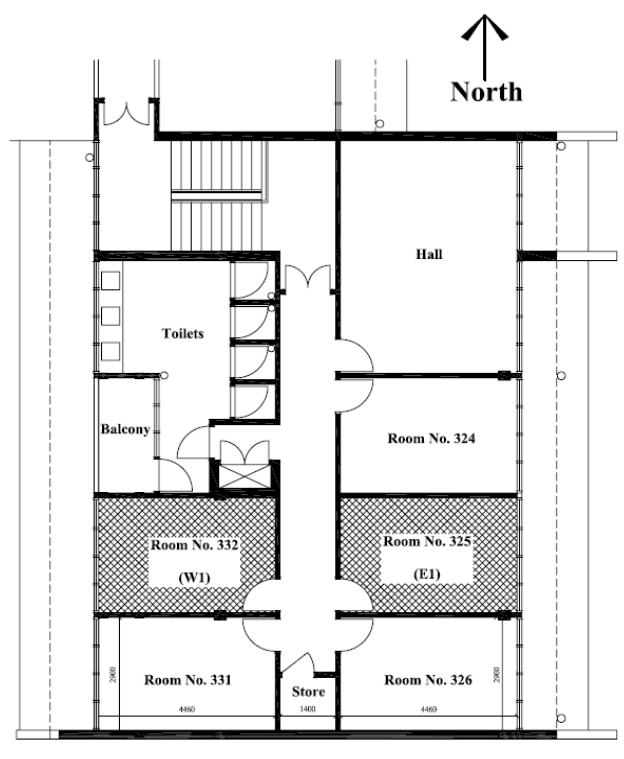

Figure 1. Plan of a full unit at third floor

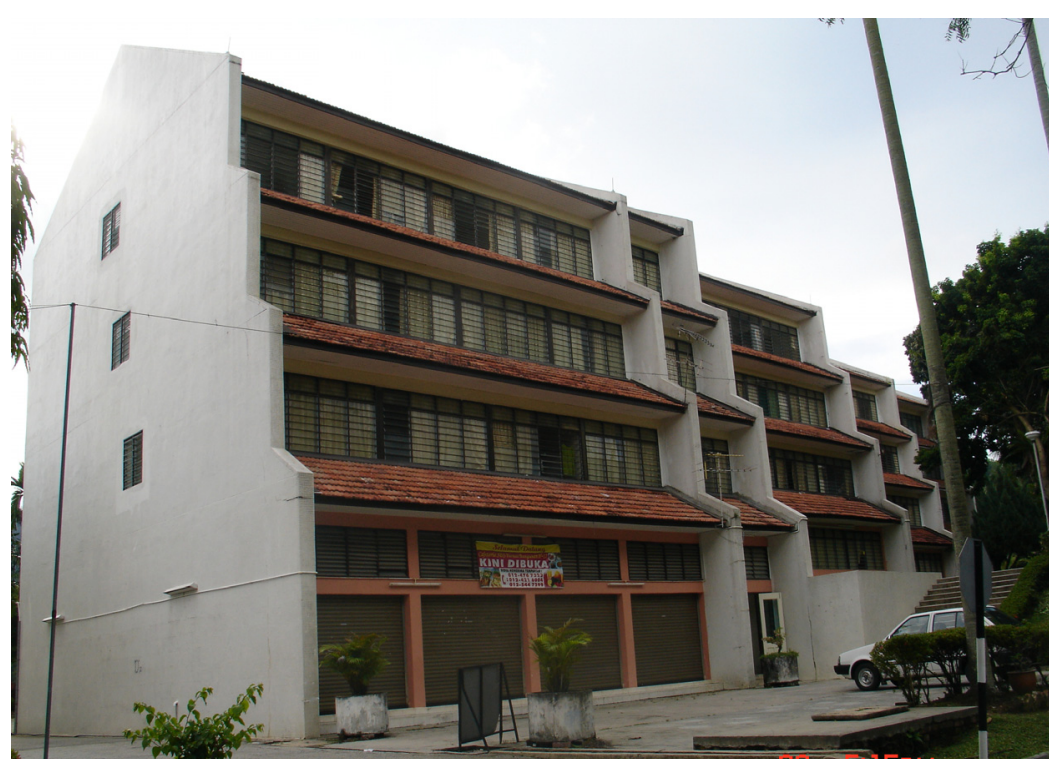

Figure 3. External and internal photos for Fajar Harapan building, USM

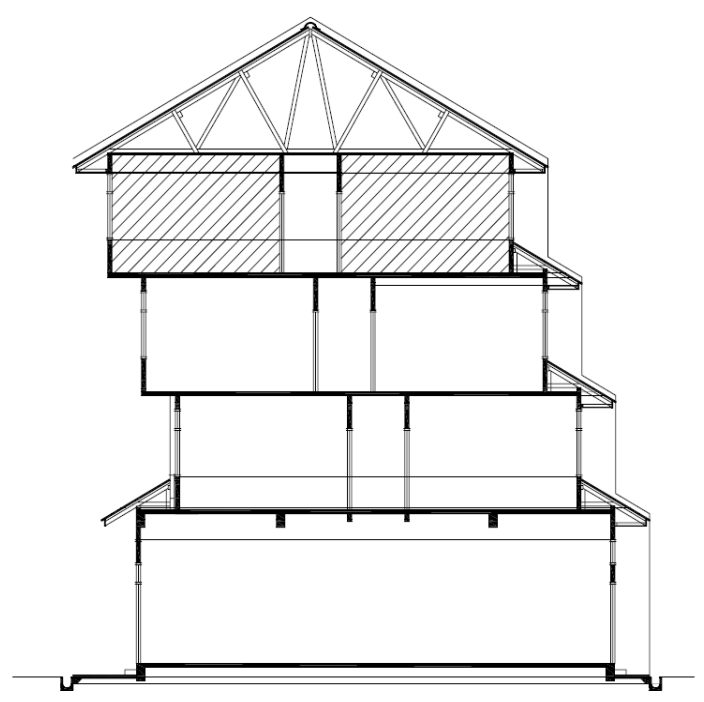

Figure 2. Cross section for the whole building
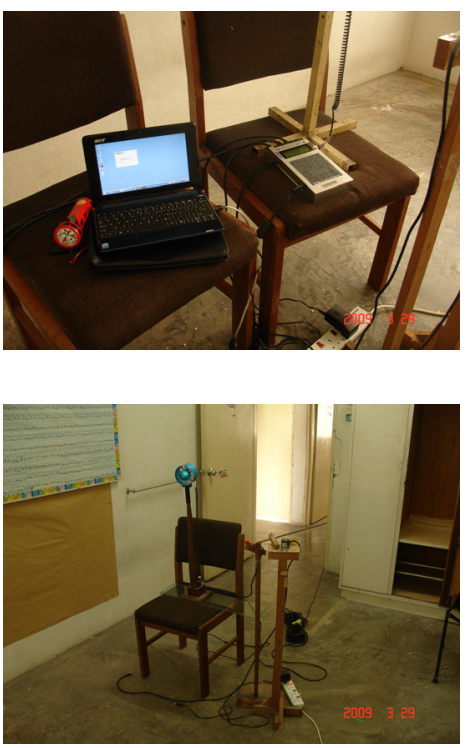


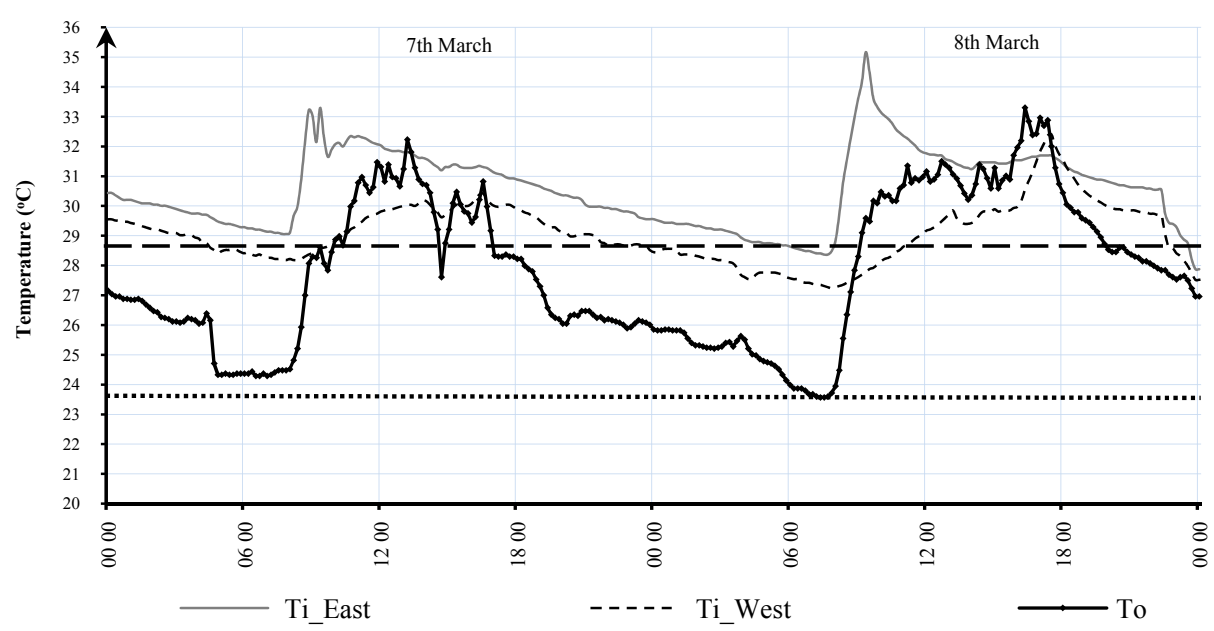

Figure 4. In/out door temperature for a typical day, unventilated rooms with $\mathrm{WWR}=50 \%$

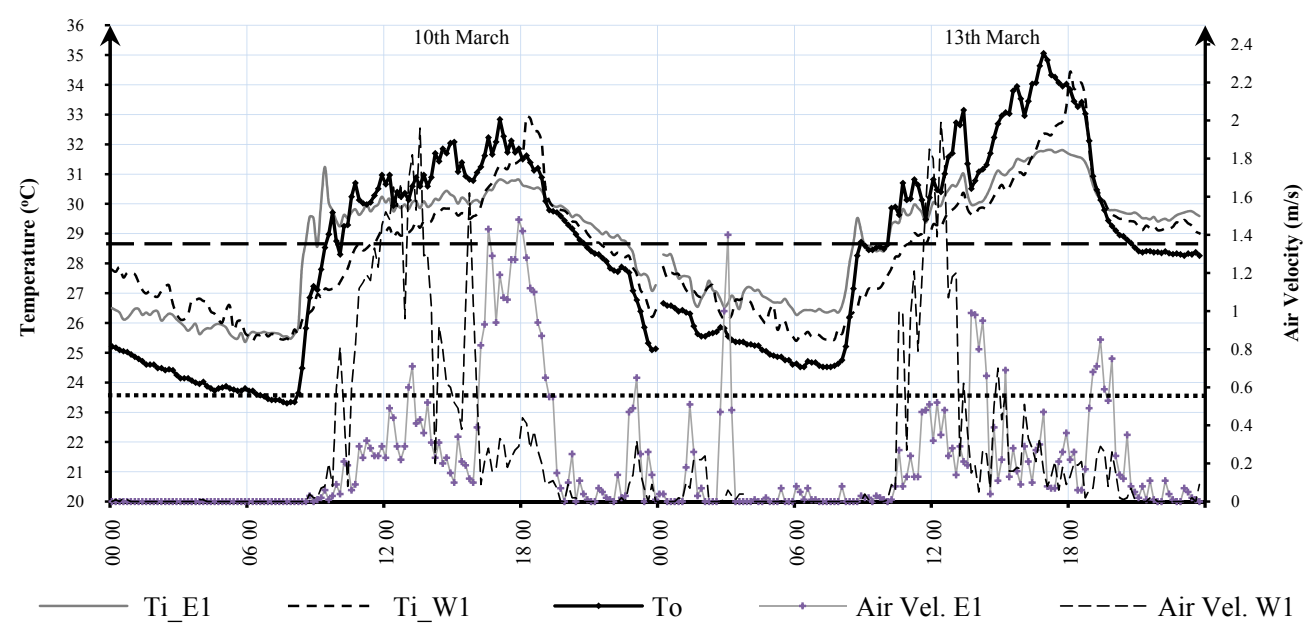

Figure 5. In/out door temperature for a typical day, ventilated rooms with $\mathrm{WWR}=50 \%$

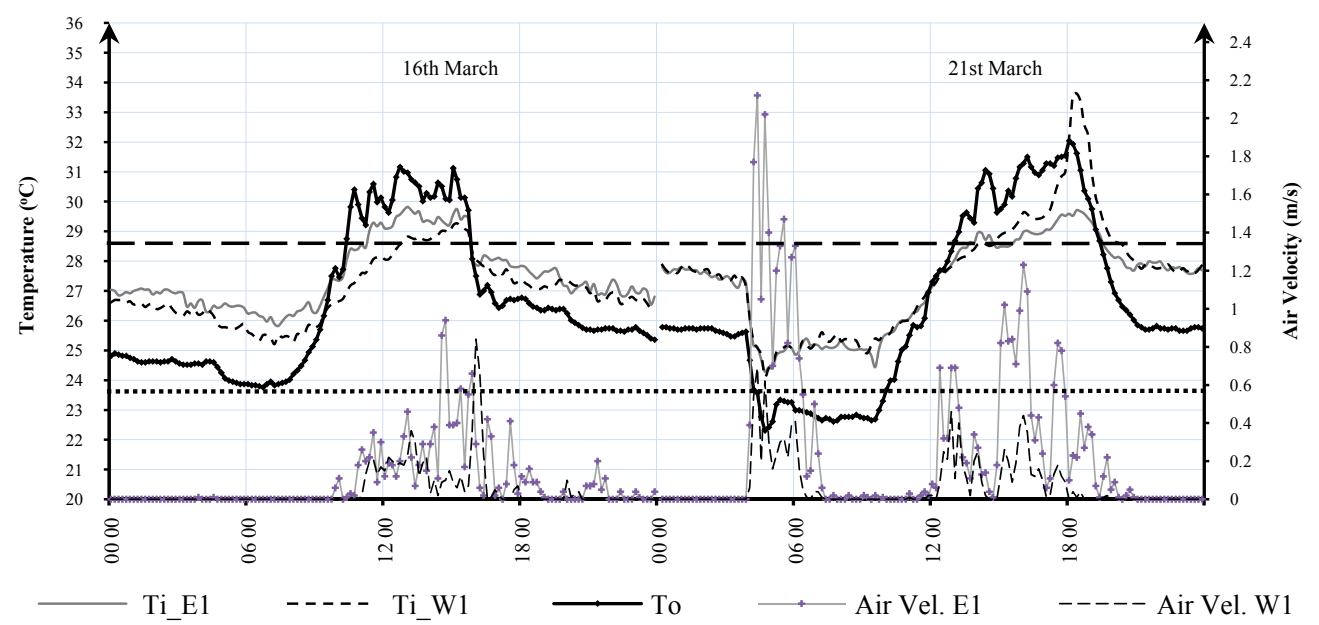

Figure 6. In/out door temperature for two typical rooms, ventilated rooms with $\mathrm{WWR}=25 \%$ 


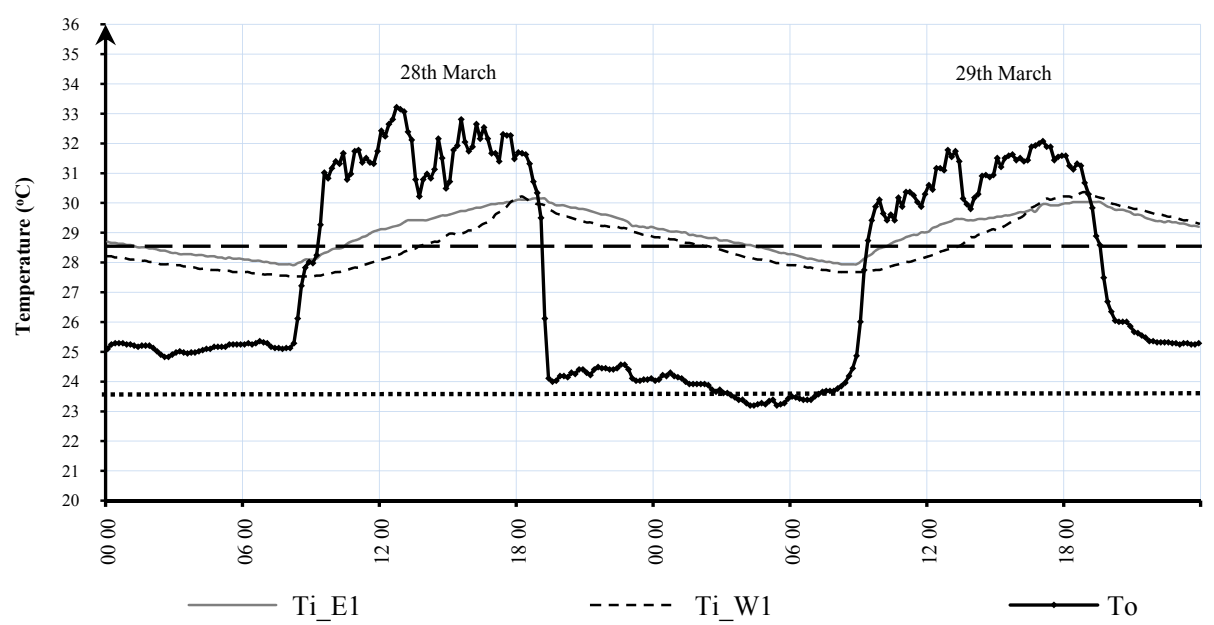

Figure 7. In/out door temperature for two typical rooms, ventilated rooms with $\mathrm{WWR}=0 \%$ 